\title{
Microbiological Studies on the Decomposition of Chitin in Marine Environment-I*
}

\author{
Occurrence of Chitinoclastic Bacteria in the Neritic Region
}

Humitake SEKI ${ }^{* *}$ and Nobuo TAGA ${ }^{* * *}$

\begin{abstract}
The occurrence of chitinoclastic bacteria growing on plankton, suspended matter and in sea water at Aburatsubo Inlet was investigated for over a period of nearly one year. The results obtained are summarized as follows :

1. Marine chitinoclastic bacteria is widely distributed in sea water, on plankton and on suspended matter. The chitinoclastic bacteria constitutes less than $0.4 \%$ of the total bacterial number in the neritic region.

2. The percentage of the chitinoclastic bacteria in the bacterial flora of suspended matter was higher than that obtained for plankton. A considerable number of chitinoclastic bacteria are, however, already attached on living copepods, and a correlation between the percentage of chitinoclasts in the bacterial flora of plankton and the percentage of planktonic crustaceans in plankton was observed.

3. The bacterial population in sea water, on plankton and on suspended matter increased slightly in summer and autumn, though their abundance was nearly equal all through the year. The percentage of chitinoclastic bacteria in each substratum showed an inverse relation with the COD of sea water.

4. All the isolated chitinoclastic bacteria were classified into the types of 5 species. Type LI appeared in Aburatsubo Inlet predominantly in summer, and Type HY appeared in winter and early spring, whereas Type IN and Type $\mathrm{CH}$ were always found on plankton and on suspended matter all through the year though they appeared dominantly in late spring and autumn while the interchange of Type LI and Type HY occurred in summer and winter and early spring respectively.

5. From experiments on the decomposition of Artemia in sea, it was found that the decomposition and liberation of easily destructible organic matter from plankton occurred within 4 days and the indestructible organic matter from plankton as chitin was later destroyed slowly. The increase of the bacterial population was rapid on dead Artemia and reached the stationary phase on the 4 th day, whereas chitinoclastic bacteria increased rapidly 2 days after Artemia died.
\end{abstract}

\section{Introduction}

In the oceans, copepods have a wide distribution and are abundant both in volume and variety. From data obtained from chemical analysis, about 5 percent of the dry weight of copepods is chitin, the chief constituent of the exoskeleton of copepods (STEUER, A., 1910). It has been estimated by JOHNSTONE (1908) that just this one order of planktonic crustaceans produces several million tons of chitin annually. As chitin occurs in the exoskeleton of crustaceans, in some mollusks, coelenterat-

* Received March 26, 1963

** Faculty of Agriculture, University of Tokyo

*** Ocean Research Institute, Uuiversity of Tokyo es, protozoans, and in the cell wall of certain lower fungi and filamentous yeast, the production of chitin in the oceans is believed to be much more abundant.

ZOBELL and RITTENBERG (1937) reported that most of the chitin is probably utilized by biological agents because little of it accumulates in marine sediments. Moreover, if it were not decomposed, there would be a serious drain of carbon and nitrogen in their respective cycles. Since there are few animals that can attack chitin it is generally agreed that its decomposition is largely due to microbial action.

Many kinds of chitinoclastic bacteria have 
been isolated from marine and fresh-water sources and studied for their properties by JOHNSON (1931), BENTON (1934), ZoBELL and RitTENBERG (1937), HOCK (1941), CAMPBELL and WILliAMS (1951), and KIHARA and MOROOKA (1962) but the relationship between chitinoclastic bacteria and plankton in the oceans has not been studied.

As the complex organic compounds found in plankton must be decomposed by the activities of bacteria to chemically simpler compound, and chitin found in planktonic crustaceans must be one of the most indestructible organic matters, it is necessary to investigate the decomposition of chitin by chitinoclastic bacteria in order to know the endpoint of the decomposition of plankton.

Suspended matters composed of dead plankton are mineralized while floating in the sea and the rest form a part of the sediments, Therefore, the present experiments were designed to investigate, in nature, the interrelations of chitinoclastic bacteria, sea water, plankton and suspended matter so as to know the role played by bacteria upon the decomposition of plankton in the neritic region.

\section{Methods}

\section{Sampling}

The sampling station was chosen at the entrance of Aburatsubo Inlet in Misaki of Kanagawa Prefecture, Japan.

Sea water was collected asceptically in a sterile glass bottle at a depth of $30 \mathrm{~cm}$. Zooplankton was collected in horizontal hauls with a plankton net (bolting silk No. 3) at surface water. Suspended matter was collected in a cleaned glass bottle (mouth dia.: $10 \mathrm{~cm}$, volume: $1 l$ ) kept submerged at a depth of $4 \mathrm{~m}$ for 15 hours.

\section{Volume of plankton and suspended matter}

Volumes are weighted as dry weight (dried for one hour at $80^{\circ} \mathrm{C}$ ).

\section{Media}

The media used for enumeration of bacteria had the following composition.

1) Modified Medium 2216 (OPPENHEIMER and ZOBELL, 1952)

Polypeptone (Daigo-eiyo-kagaku): $5 \mathrm{~g}$
Ferric phosphate soluble (Merck): $0.1 \mathrm{~g}$

Agar (Wako): $\quad 15 \mathrm{~g}$

Aged sea water:

$1 l$

$\mathrm{pH}$ adjusted to 7.6-7.8.

2) Campbell's basic medium (CAMPBELL and WILLIAMS, 1951)

$\mathrm{K}_{2} \mathrm{HPO}_{4}$ :

$\mathrm{MgSO}_{4}$ :

$1 \mathrm{~g}$

$\mathrm{CaCl}_{2}$ :

$0.05 \mathrm{~g}$

$\mathrm{NaCl}$ :

$0.1 \mathrm{~g}$

$20 \mathrm{~g}$

Ferric phosphate soluble (Merck): trace

Distilled water : $\mathrm{pH}$ adjusted to 7.0 .

Chitin was prepared from the exoskelenton of Paralithodes camtschaticus by the method of BENTON (1935).

Isolation of bacteria from plankton and suspended matter

Samples were homogenized in a sterile blender containing $20 \mathrm{ml}$ of sterilized sea water with 2 to 3 ppm Tween 80 (JoNEs, G.E., 1956). Homogenization was conducted at $20^{\circ} \mathrm{C}$ for 2 minutes after which parts of the homogenate were used as samples for enumeration.

\section{Counting of bacteria}

1) Chitinoclastic bacteria

The approximate numbers of chitinoclastic bacteria were determined by the dilution method of HALVORSON and ZIEGLER (1933). The chitin medium for this purpose was prepared by strips of purified chitin in test tubes with Campbell's basic medium and sterilized at $120^{\circ} \mathrm{C}$ for 20 minutes. The innoculated media were incubated at $20^{\circ} \mathrm{C}$ and examined after 30 days for the evidence of chitinoclastic activity, $i$. $e$. the visible dissolution of chitin.

Thus the most probable number (MPN) of chitinoclastic bacteria was estimated from the distribution of positive and negative tubes using the table of Hoskins (1934).

2) Total bacteria

Total bacterial number as control was estimated by the agar pour plate method. The medium for this purpose was Modified Medium 2216. The plates were incubated for 10 days before counting colonies. Colonies were counted with Quebec Colony Counter.

Identification of marine chitinoclastic bacteria In Bergey's Manual of Determinative Bac- 
teriology, 7 th edition, only seven species of chitinoclastic bacteria have been identified, six of which belong to the genus Beneckea and the 7 th belongs to the genus Micrococcus. CAMPBEll and Williams (1951) identified two other species of chitinoclastic bacteria, for which they propose the names Pseudomonas cryothasia and Pseudomonas subrubra.

Thirty nine cultures of chitinoclastic bacteria were isolated. Isolation was done by making streaks on the chitin agar plates. These were examined daily for the appearance of haloes surrounding the colonies, which are indicative of chitin decomposition.

Chitin agar plates used for the isolation of chitinoclastic bacteria were prepared by the method of CAMPBELL and Williams (1951). The purified chitin strips were dissolved in $50 \% \mathrm{H}_{2} \mathrm{SO}_{4}$ and precipitated by rapid dilution with 15 fold volume of water. The resulting finely divided chitin was free from acid by washing on a Buchner funnel until the filtrate was neutral to litmus. This wet material was incorporated into Campbell's basic medium base agar.

Estimation of COD (Chemical oxgen demand)

The fluctuation of total amount of organic matters in sea water was indicated with the value of oxygen consumed from the alkaline potassium permanganate solution. The detailed analytic procedure was as follows: Place a $50 \mathrm{~m} l$ sample in the Erlenmyer flask and add one $\mathrm{ml} 3 \mathrm{~N} \mathrm{NaOH}$. Carefully add $10 \mathrm{~m} l$ $1 / 100 \mathrm{~N} \mathrm{KMnO}_{4}$, mixing after each addition. Heat the mixture in steam bath at $100^{\circ} \mathrm{C}$ for 30 minutes. Add $0.1 \mathrm{~g} \mathrm{KI}$ and cool. After cooling to room temperature, add $1 \mathrm{ml} 9 \mathrm{~N}$ $\mathrm{H}_{2} \mathrm{SO}_{4}$ and titrate the excess $\mathrm{KMnO}_{4}$ with $1 / 100 \mathrm{~N} \mathrm{Na}_{2} \mathrm{~S}_{2} \mathrm{O}_{3}$, using starch indicator. A blank consisting of $50 \mathrm{~m} l$ distilled water instead of the sample, is treated with the same manner as above mentioned. Then the COD value of the water sample is calculated by the substruction of the titrated value of sample from that of blank.

\section{Results and discussions}

\section{1) Classification of marine chitinoclastic bacteria}

39 pure cultures of chitinoclastic bacteria were isolated and they were classified into 5 types in accordance to Bergey's Manual of Determinative Bacteriology, 7 th edition and the report of CAMPBELL and WILLIAMS (1951).

Type IN

Rods, 0.5 to 1.0 by 1.0 to 2.0 microns. Motile by means of peritrichous flagella. Gramnegative.

Gelatin stab: Crateriform liquefaction.

Agar slant: Yellow to yellow orange, smooth, opaque growth.

Peptone broth: Turbid; slight surface scum; yellow to yellow orange sediment

Litmus milk: Acid in 2 days.

Indol is produced.

Hydrogen sulfide not produced.

Acid but no gas from glucose and sucrose.

Chitin is hydrolyzed.

Nitrites produced from nitrates.

Ammonia produced from peptone.

Optimum temperature, between $20^{\circ} \mathrm{C}$ and $30^{\circ} \mathrm{C}$.

Source: Isolated from plankton and suspended matter in Aburatsubo Inlet.

This type seems to be analogous to Beneckea indolthetica Campbell, comb. nov.

\section{Type $\mathrm{CH}$}

Rods, 1 by 2 microns. Motile by means of peritrichous flagella. Gram-negative.

Gelatin stab: Crateriform liquefaction.

Peptone broth: Turbid with heavy, slimy, whitish pellicle.

Indol not produced.

Hydrogen sulfide not produced.

Acid but no gas from glucose and sucrose.

Chitin is hydrolyzed.

Nitrites produced from nitrates.

Ammonia produced from peptone.

Optimum temperature, between $30^{\circ} \mathrm{C}$ and $40^{\circ} \mathrm{C}$.

Source: Isolated from plankton and suspended matter in Aburatsubo Inlet.

This type seems to be analogous to Beneckea chitinovora. Campbell, comb. nov. 


\section{Type LI}

Rods, 0.5 by 1 to 2 microns. Motile by means of peritrichous flagella. Gram-negative.

Gelatin stab: Crateriform liquefaction.

Agar slant: Abundant, filiform, glistening, opaque, non-pigmented growth.

Peptone broth: Uniformly turbid.

Litmus milk: Acid in 4 days.

Indol not produced.

Hydrogen sulfide not produced.

Acid but no gas from glucose. No acid from sucrose.

Chitin is hydrolyzed.

Nitrites not produced from nitrates.

Ammonia produced from peptone.

Growth not inhibited by $10 \% \mathrm{NaCl}$.

Aerobic, facultative.

Optimum temperature, between $20^{\circ} \mathrm{C}$ and $35^{\circ} \mathrm{C}$.

Source: Isolated from sea water, suspended matter and plankton in Aburatsubo Inlet.

This type seems to be analogous to $B e$ neckea lipophaga Campbell, comb. nov.

\section{Type HY}

Rods, 0.5 by 1 micron. Motile by means of peritrichous flagella. Gram-negative.

Gelatin stab: Grateriform liquefaction.

Agar slant: Beaded, glistening, opaque, non-pigmented.

Peptone broth: Moderately turbid: surface ring adherent to the walls of the tubes.

Litmus milk: Alkaline, in 4 days.

Indol not produced.

Hydrogen sulfide not produced.

Acid but no gas from glucose. No acid from sucrose.

Chitin is hydrolyzed.

Nitrites produced from nitrates.

Ammonia produced from peptone.

Growth not inhibited by $10 \% \mathrm{NaCl}$.

Aerobic, facultative.

Optimum temperature, between $20^{\circ} \mathrm{C}$ and $30^{\circ} \mathrm{C}$

Source: Isolated from sea water, plankton and suspended matter in Aburatsubo Inlet.
This type seems to be analogous to Beneckea hyperoptica Campbell, comb. nov.

\section{Type LA}

Rods, 0.5 by 1 micron. Motile by means of peritrichous flagella. Gram-negative.

Gelatin stab: No liquefaction.

Agar slant: Abundant, filiform, smooth, glistening, opaque, non-pigmented.

Peptone broth: Moderately turbid; surface growth adherent to the walls of the tubes.

Litmus milk: Acid in 6 days.

Indol not produced.

Hydrogen sulfide not produced.

Acid but no gas from glucose. No acid from sucrose.

Chitin is hydrolyzed.

Nitrites produced from nitrates.

Ammonia produced from peptone.

Aerobic, facultative.

Optimum temperature, between $20^{\circ} \mathrm{C}$ and $30^{\circ} \mathrm{C}$.

Source: Isolated from intestinal tract of squid.

This type seems to be analogous to Beneckea

labra Campbell, comb. nov.

2) Seasonal distribution of chitinoclastic bactcria

Total bacteria and the number of chitinoclastic bacteria present in the samples of sea water, plankton and suspended matter were enumerated monthly. The bacterial populations in various substrata examined are presented in Fig. 1, and the percentages of chitinoclastic bacteria in the bacterial flora are as shown in Fig. 2.

From Fig. 1 it was found that the bacterial population in each substratum fluctuated somewhat seasonally, $i$. $e$. a very slight increase of the population was detected, especially in summer and autumn, though the abundance was nearly constant through the year. This slight fluctuation may be chiefly attributed to the size and shape of planktons, size of suspended matter and the amount of dissolved organic matter.

The remarkable fluctuation of chitinoclastic bacteria in the bacterial flora of different sub- 


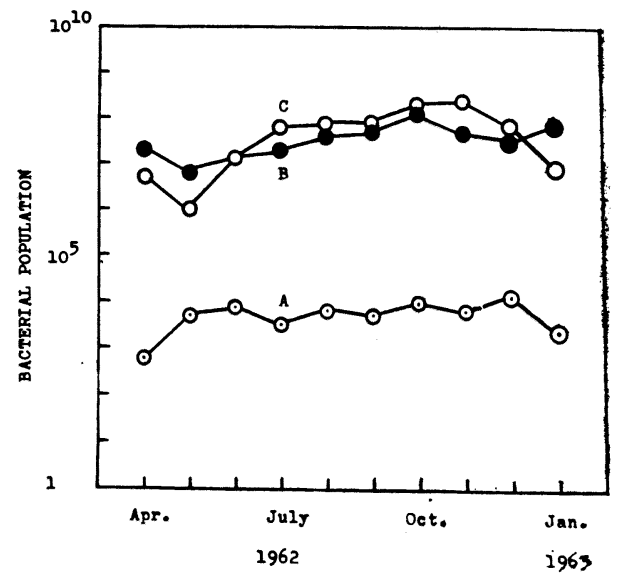

Fig. 1. The seasonal fluctuations of the bacterial populations in sea water, on plankton and on suspended matter at Aburatsubo Inlet.

A: bacterial population in sea water

B : bacterial population on plankton

C: bacterial population on suspended matter

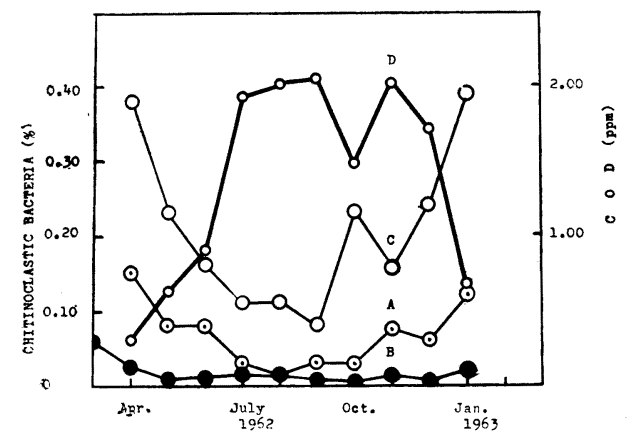

Fig. 2. The percentage of chitinoclasts in the bacterial flora in various substrata.
A : chitinoclasts in sea water
B : chitinoclasts on plankton
C: chtinoclasts on suspended matter
D: COD of the sea water

stratum (sea water, plankton and suspended matter) is as shown in Fig. 2. The percentages of chitinoclastic bacteria in each of the substrata showed an inverse relation with COD (Chemical oxygen demand) of the sea water. Even in suspended matter chitinoclastic bacteria was less than $0.4 \%$ of the total bacterial number. This percentage, however, is higher than that of the result obtained from plankton, though the total bacterial number on plankton and suspended matter is of the same order.
The number of chitinoclastic bacteria from sea water is equal to the mean value of that obtained from plankton and suspended matter.

A considerable number of chitinoclastic bacteria are already attached on living copepods. As mentioned above, however, they are less than $0.05 \%$ of the total bacterial number. Fig. 3 shows the relationship between the percentage of chitinoclastic bacteria and the volume

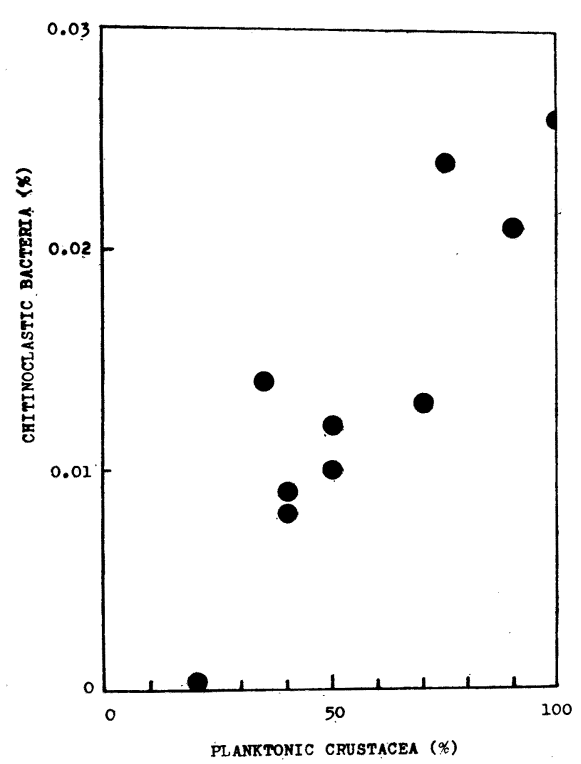

Fig. 3. The relation between the percentage of chitinoclasts in the bacterial flora on the plankton and the percentage by volume of the planktonic crustacea in the plankton collected at Aburatsubo Inlet.

of planktonic crustaceans present in the plankton collected. A correlation between them was observed. As has been mentioned above the same order of total bacterial number on plankton was observed. These phenomena might indicate that the beneficial effect of solid surface of any kind of plankton is equal on the whole for the accumulation of organic matter in sea water and also for the retardation of diffusion of exoenzymes from bacteria that are attributed to the plankton. This correlation, therefore, may be considered due to the constituent of the exoskeleton in plankton. In Aburatsubo Inlet the most popular plankton is Noctiluca and the dominant planktonic 
crustaceans are Acartia, Paracalanus, Penilia, Evadne and Podon.

From the fact mentioned above it is seen that the chitinoclastic bacteria predominate in the planktonic crustaceans. This may perhaps be due to the fact that the chitinoclastic bacteria attack the chitin of the exoskeleton of planktonic crustaceans and therefore survive bacterial antagonism.

A considerable number of chitinoclastic bacteria are already attached to the exoskeleton during ecdysis and also when the planktonic crustaceans are dead.

This may be one of the chief reasons why little chitin accumulates in marine sediments.

Chitinoclastic bacteria found in the various substrata examined are as shown in Table 1.

As shown in Table 1, Type LI appeared in Aburatsubo Inlet predominantly during summer, and Type HY appeared during winter and early spring. This may largely be correlated with water temperature as will be shown later. Isolates from plankton always contain the same species that are obtained from sea water. Type IN and Type $\mathrm{CH}$ were always found on plankton and suspended matter throughout the year, and appeared dominantly in late spring and autumn while the interchange of Type LI and Type HY occurred in the seasons as mentioned above.
3) Experimental observation on the bacterial flora of a planktonic crustaceans

While dead planktonic crustaceans are subject to bacterial attack, the chemical constituent of the dead plankton must also vary according to the variation in nutritional resource.

Brine shrimp, Artemia salina Leach, were cultured in a bacteria-free condition, after they had hatched, for a month. They were then transferred to an aquarium tank with the pump system of running raw sea water in situ. After a week they were killed by cooling the rearing water to $10^{\circ} \mathrm{C}$ from $21^{\circ} \mathrm{C}$ during one minute, and they were put into the cleaned Nylon-net container, subsequently was it submerged in the aquarium tank, which was practically reproduced the environmental conditions of the sea in situ.

Both living and dead brine shrimps were homogenized for 2 minutes in a sterile blender containing $20 \mathrm{ml}$ of sterilized sea water with 2 to $3 \mathrm{ppm}$ Tween 80 . Parts of the homogenate were used as samples. Observations of bacteria on brine shrimps were carried out both before and after the brine shrimps were killed.

The results obtained are summarized in Fig. 4 and Fig. 5.

The rapid destruction of Artemia was observed in natural sea water. About $90 \%$ by weight disappeared at $21^{\circ} \mathrm{C}$ in 4 days. This may not only be due to microbial action, but

Table 1. Marine chitinoclastic bacteria predominating in the sea of Aburatsubo Inlet.

\begin{tabular}{l|c|c|c}
\hline \multirow{2}{*}{ Date of collection } & \multicolumn{3}{|c}{ Bacterial type in various substrata* } \\
\cline { 2 - 4 } & Sea water & Plankton & Suspended matter \\
\hline Apr. 13, 1962 & HY & $\mathrm{CH}$ & IN, CH \\
May 11, 1962 & $\mathrm{HY}$ & $\mathrm{HY}$ \\
Jun. 12. 1962 & $\mathrm{HY}$ & $\mathrm{HY}$ & $\mathrm{HY}$ \\
Jul. 12, 1962 & LI, IN & IN \\
Aug. 12, 1962 & LI & LI & LI, IN \\
Sept. 12, 1962 & LI, HY & LI & $\mathrm{CH}, \mathrm{IN}$ \\
Oct. 12, 1962 & $\mathrm{HY}$ & $\mathrm{CH}$ & $\mathrm{HY}, \mathrm{IN}$ \\
Nov. 12, 1962 & $\mathrm{HY}$ & $\mathrm{HY}, \mathrm{CH}$ & $\mathrm{CH}$ \\
Dec. 11, 1962 & $\mathrm{CH}$ & $\mathrm{CH}$ & $\mathrm{HY}, \mathrm{IN}$ \\
Jan. 12, 1963 & $\mathrm{HY}$ & $\mathrm{CH}$ & $\mathrm{IN}, \mathrm{CH}$ \\
\hline
\end{tabular}

*Abbreviation of bacterial type presented in this report. 


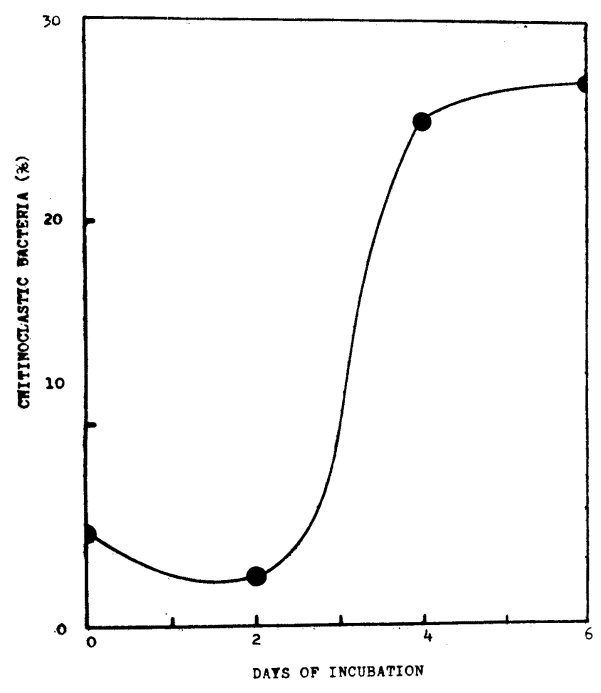

Fig. 4. Chitinoclasts in the bacterial flora on putrefying Artemia submerged in sea water in Aburatsubo Inlet.

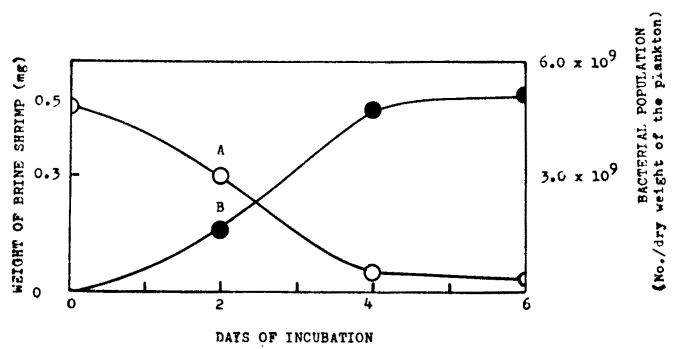

Fig. 5. Breakdown of dead Artemia and bacterial population in them in running raw sea water. Environmental conditions (Oct. 1962) $\begin{array}{lr}\text { Water temperature: } & 21 \pm 2^{\circ} \mathrm{C} . \\ \mathrm{Cl}(\% 00): & 18.96 . \\ \mathrm{pH}: & 8.2\end{array}$

Total bacteria in sea water: $10000 / \mathrm{ml}$.

Chitinoclasts in sea water (MPN): $110 / \mathrm{ml}$.

A: weight of brine shrimp

B : bacterial population

also due to mechanical action of running sea water $(30 \mathrm{~cm} / \mathrm{min}$.). The number of total marine bacteria found on the dead plankton at different stages of putrefaction were as follows: $1.2 \times 10^{8} / \mathrm{g}$-Artemia(0 day), $1.6 \times 10^{9} / \mathrm{g}$ Artemia ( 2 days), $3.7 \times 10^{9} / \mathrm{g}$-Artemia (4 days), $5.1 \times 10^{9} /$ g-Artemia (6 days).

The portion of chitinoclastic bacteria in the flora on living Artemia was only $4.9 \%$, but the portion on the dead plankton increased rapidly 2 days after the plankton were killed and increased to $25 \%$ in 4 days. The total bacteria on living Artemia were much more abundant than those on copepods. This may be due to the feathery structure of Artemia.

Most parts of the dead Artemia were destroyed within 4 days and thereafter the destruction was not so rapid. The increase of the bacterial population on dead Artemia was remarkable and attained the stationary phase 4 days after the plankton died. The faint increase of the population thereafter may be due to the increase of solid surfaces of Artemia caused by putrefaction. Chitinoclastic bacteria increased slowly after Artemia died but the increase was rapid after 2 days. These facts therefore suggest that decomposion and liberation of easily destructible organic matter may occur in 4 days and indestructible substances such as chitin may be destroyed slowly thereafter.

The bacterial population on dead plankton was much more abundant than that obtained in the previous observations in situ, where the suspended matter was regarded as dead plankton in the region. Suspended matter in the sea, however, includes detritus matters of dead zooplankton, phytoplankton and even inorganic particles (silt), the organic constituents that can be utilized by marine bacteria per fundamental unit of suspended matter must be less than that of the dead plankton as in the present observation. This may be the reason why the bacterial population on the dead plankton was more abundant than that on suspended matter in the sea as has been obtained previously.

\section{Acknowledgement}

The authors are much indebted to Dr. Yoshiyuki MATSUE, Professor of the University of Tokyo, for his constant guidance during the course of this work.

\section{References}

AIkAWA, H. (1942): Marine planktology, Suisansha. 108-111. (Jap.)

Benton, A. G. (1934): Chitinovorous bacteria. A preliminary survey. Jour. Bact., 29, 449-465.

Breed, R. S., E. G. D. MURRAY and N. R. SMith. 
(1957): Bergey's Manual of Determinative Bacteriology, 7th edition., Baltimore, The Williams and Wilkins Company.

Campbell, L. L. and O. B. Williams (1951): A study of chitin-decomposing micro-organisms of marine origin. Jour. gen. Microbiol., 5, 894905.

Hock, C. W. (1941): Marine chitin-decomposing bacteria. Jour. Mar. Res., 4, 99-106.

Johnson, D. E. (1931): Some observarions on chitin-destroying bacteria. Jour. Bact., 24, 335340.

Johnstone, J. (1908): Conditions of Life in the Sea. Cambridge Univ. Press.

Jones, G. E. and H. W. JANnAsch (1956): Aggregates of bacteria in sea water as determined by treatment with surface active agents. Limnol. Oceanogr., 4 (3), 269-275]
KIHARA, K. and N. MorooKA (1962): Studies on chitin-decomposing bacteria (1) Classification and description of species. Jour. Oceanogr. Soc. Japan, 16(3), 147-152.

NAKAI, J. (1942): Chemical constituents, volumes and weights of 10 species of staple marine plankton. Jour. Oceanogr. Soc. Japan, 1(1), 45-55. (Jap.)

Skinner, C. E. and F. Dravis (1937): A quantative determination of chitin destroying microorganisms in soil. Ecology, 18 (3), 391-397.

ZoBell, C. E. and S. C. Rittenberg (1937): The occurrence and characteristic of chitinoclastic bacteria in the sea. Jour. Bact., 35(3), 275-287.

ZoBell, C. E. (1941): Studies on marine bacteria I. The cultural requiremehts of heterotrophic aerobes. Jour. Mar. Res., 4(1), 42-75.

ZoBell, C. E. (1946): Marine Microbiology. Chronica Botanica Co. 